\title{
Routine versus selective use of episiotomy in primigravida: a prospective non-randomized case-control study
}

\author{
Dipti A. Modi, Palak P. Vaishnav*
}

Department of Obstetrics and Gynecology, Baroda Medical College, Vadodara, Gujarat, India

Received: 29 December 2019

Revised: 17 January 2020

Accepted: 24 January 2020

\section{*Correspondence:}

Dr. Palak P. Vaishnav, E-mail: drpalak11@gmail.com

Copyright: (c) the author(s), publisher and licensee Medip Academy. This is an open-access article distributed under the terms of the Creative Commons Attribution Non-Commercial License, which permits unrestricted non-commercial use, distribution, and reproduction in any medium, provided the original work is properly cited.

\section{ABSTRACT}

Background: Episiotomy is a surgically planned incision on the perineum and the posterior vaginal wall during second stage of labour. It is an inflicted second-degree perineal tear. Objective of this study was to determine the possible benefits and risks of the use of selective episiotomy versus routine episiotomy during delivery in primigravida.

Methods: This is a prospective non-randomized case-control study designed to analyze and compare the maternal outcomes following routine versus selective use of episiotomy in primigravida. In control group, 122 patients were recruited and mediolateral episiotomy was given in all patients; while in study group, 61 patients were recruited, in whom episiotomy was given selectively.

Results: In study group 61 patients were recruited, out of which episiotomy can be avoided in 23 (37.7\%) of cases. There was no $3^{\text {rd }}$ or $4^{\text {th }}$ degree perineal tear found in any group. Perineal pain score on $3^{\text {rd }}$ day postpartum was less in study group, as compared to control group on bed rest, sitting, walking and defecation.

Conclusions: Selective use of episiotomy can improve maternal outcome by reducing perineal lacerations and those having intact perineum can have the best outcome when episiotomy is given selectively.

Keywords: Episiotomy, Perineal pain, Perineal tear, Routine, Selective use

\section{INTRODUCTION}

Episiotomy is a surgically planned incision on the perineum and the posterior vaginal wall during $2^{\text {nd }}$ stage of labour. It is an inflicted second-degree perineal tear. ${ }^{1}$ It is one of the most commonly performed surgical procedures in the world, particularly for primigravida women. Two types of episiotomy have been described: midline (median) and mediolateral. Generally, midline episiotomies are more commonly performed in the United States, whereas mediolateral episiotomies are more common in other parts of the world. ${ }^{2}$ Though there has been no strong scientific evidence of its effectiveness, it is used extensively specifically in primipara with the belief that it's easier to suture clean cut episiotomy than vaginal lacerations.

The other reasons commonly used to justify routine episiotomy are: (1) It facilitates delivery resulting in less trauma to baby and improved Apgar and fewer ICU admissions. (2) Surgical healing is better and fewer $3^{\text {rd }}$ and $4^{\text {th }}$ degree perineal tears resulting in less pain, bleeding, infection, dyspareunia as short term benefits and less dyspareunia, fecal incontinence, urinary incontinence and lesser chances of rectal and urinary fistula and prolapse. On the other hand, hypothesized adverse effects of routine use of episiotomy include: (1) $3^{\text {rd }}$ and $4^{\text {th }}$ degree perineal tear by unavoidable extension 
of the incision which can secondarily lead to anal incontinence, rectovaginal fistula. (2) unsatisfactory anatomic results such as skin tags, asymmetry or excessive narrowing of the introitus.(3) increased blood loss and hematoma formation(4) pain and oedema in the episiotomy region (5) infection and dehiscence (6) dyspareunia. ${ }^{3}$ Other important issues to bear in mind are costs and additional resources that may be required to sustain a policy of routine use of episiotomy.

The American College of Obstetricians and Gynaecologists has concluded: "Data show no immediate or long-term maternal benefit of routine episiotomy in perineal laceration severity, pelvic floor dysfunction, or pelvic organ prolapse compared with restrictive use of episiotomy. Moreover, episiotomy has been associated with increased risk of postpartum anal incontinence. Current data and clinical opinion suggest that there are insufficient objective evidence-based criteria to recommend episiotomy, especially routine use of episiotomy, and that clinical judgment remains the best guide for use of this procedure. ${ }^{4}$

\section{METHODS}

This is non-randomized prospective case-control study carried out in the department of obstetrics and gynaecology, Shree Sayajirao general hospital, Vadodara from February 2018 to September 2018, designed to analyze and compare the maternal outcomes following routine versus selective use of mediolateral episiotomy in primigravida. In control group, 122 patients were recruited and mediolateral episiotomy was given in all patients; while in study group, 61 patients were recruited, in whom episiotomy was given selectively.

Written and informed consents from all the participants of the study were obtained.

\section{Inclusion criteria}

- $\quad$ Primigravida

- Irrespective of their age

- 36 to 42 weeks pregnancy

- With a single live fetus

- In cephalic presentation

- In whom delivery was conducted by vaginal route.

\section{Exclusion criteria}

- Malpresentation

- Malposition

- Instrumental delivery $\mathrm{F}$ et al., macrosomia (expected fetal weight $>3.5 \mathrm{~kg}$ ) and

- High risk pregnancy including hypertensive disease of pregnancy, mother having systemic disease, multiple pregnancies, prolonged rupture of membrane.
T controls were selected from other unit of obstetrics and gynaecology department, including all the patients who have been given mediolateral episiotomy on routine basis with or without specific indication. Cases were selected from our unit in whom the episiotomy was given selectively, based on clinical judgment, as in whom there was fetal distress, the perineum was found not able to accommodate delivery without episiotomy (Rigid perineum), imminent perineal tear and prolonged second stage of labour.

\section{Statistical analysis}

Statistical analysis was done by Medcalc statistical software 17.2. Continuous variables were presented as mean \pm SD and categorical variables were presented by Absolute number and percentage. $\mathrm{p}$ value was calculated by two-tailed t-test for continuous variables and by fisher exact test or chi square test for categorical variables. For assessment, $\mathrm{p}$ value less than 0.05 was considered significant.

\section{RESULTS}

In present study, both cases and controls were compared for occupation, gestational age, oxytocin use (Table 1) and maternal age, perineal length, duration of second stage of labour, birth weight (Table 2). Duration of second stage of labour and birth weight was found to be higher in study group.

In control group 122 patients were recruited and episiotomy was given in all patients; while in study group 61 patients were recruited, out of which episiotomy was given in 38(62.29\%) patients and was avoided in 23 $(37.7 \%)$ cases. In study group, 14 patients $(22.95 \%)$ had an intact perineum. Combined first degree perineal tear and intact perineum was $36.07 \%$ in study group compared to $0 \%$ in control group, means $36.07 \%$ patients had better outcome in terms of perineal tear in study group, as episiotomy is considered as second-degree perineal tear (Table 3).

No another perineal tear found in same patient in both the groups in whom episiotomy is given. Para urethral tear requiring suturing, required in one patient in study group compared to no tear in control group. There was no $3^{\text {rd }}$ or $4^{\text {th }}$ degree perineal tear found in any group.

Perineal pain score on $3^{\text {rd }}$ day postpartum was compared by visual analogue scale (VAS) between study group and control group on bed rest, sitting, walking and defecation (Table 4). The patients having intact perineum had best outcome when episiotomy was given selectively. Those having spontaneous primary perineal tear had better outcome as compared to episiotomy in terms of perineal pain. 
Table 1: Comparison of occupation, gestational age and oxytocin use between study and control group.

\begin{tabular}{|c|c|c|c|c|c|}
\hline & \multicolumn{2}{|l|}{ Study group } & \multicolumn{2}{|l|}{ Control group } & \multirow{2}{*}{$\begin{array}{l}\text { p value (fisher } \\
\text { exact test) }\end{array}$} \\
\hline & No. of cases & $\%$ & No. of controls & $\%$ & \\
\hline Total & 61 & 100 & 122 & 100 & \\
\hline \multicolumn{5}{|l|}{ Occupation } & \multirow{3}{*}{0.21} \\
\hline Heavy work (farmer/laborer) & 16 & $26.23 \%$ & 43 & $35.25 \%$ & \\
\hline Moderate work (housewife) & 45 & $73.77 \%$ & 79 & $64.75 \%$ & \\
\hline \multicolumn{5}{|l|}{ Gestational age } & \multirow{4}{*}{0.83} \\
\hline $36-37$ weeks & 12 & $19.67 \%$ & 27 & $22.69 \%$ & \\
\hline $38-39$ weeks & 39 & $63.93 \%$ & 72 & $59.02 \%$ & \\
\hline 40 weeks and above & 10 & $16.39 \%$ & 23 & $18.85 \%$ & \\
\hline \multicolumn{5}{|l|}{ Oxytocin } & \multirow{3}{*}{0.93} \\
\hline Used & 41 & $67.21 \%$ & 81 & $66.39 \%$ & \\
\hline Not used & 20 & $32.79 \%$ & 41 & $33.61 \%$ & \\
\hline
\end{tabular}

Table 2: Comparison of maternal age, perineal length, duration of second stage of labour and birth weight between study group and control group.

\begin{tabular}{|c|c|c|c|c|c|}
\hline Parameter & Group & $\mathbf{N}$ & Mean & Standard deviation & p value \\
\hline \multirow{2}{*}{ Maternal age (years) } & Study & 61 & 22.66 & 2.99 & \multirow{2}{*}{0.11} \\
\hline & Control & 122 & 23.37 & 2.76 & \\
\hline \multirow{2}{*}{ Perineal length $(\mathrm{cm})$} & Study & 61 & 3.38 & 0.38 & \multirow{2}{*}{0.08} \\
\hline & Control & 122 & 3.29 & 0.30 & \\
\hline \multirow{2}{*}{ Duration of $2^{\text {nd }}$ stage of labour ( $\mathrm{min}$ ) } & Study & 61 & 36.3 & 9.30 & \multirow{2}{*}{0.02} \\
\hline & Control & 122 & 33.36 & 7.05 & \\
\hline \multirow{2}{*}{ Birth weight (gm) } & Study & 61 & 2736.3 & 259.9 & \multirow{2}{*}{0.03} \\
\hline & Control & 122 & 2624.8 & 350.5 & \\
\hline
\end{tabular}

Table 3: Distribution by patients having intact perineum or first-degree perineal tear versus episiotomy or seconddegree perineal tear.

\begin{tabular}{|lllll|}
\hline & Cases & Cases $(\%)$ & Controls & Controls (\%) \\
\hline Intact perineum $+1^{\text {st }}$ degree tear & $14+8=22$ & $22.95+13.12=36.07 \%$ & $0+0$ & $0.00 \%$ \\
\hline Episiotomy $+2^{\text {nd }}$ degree tear & $38+1=39$ & $62.29+01.63=63.93 \%$ & $122+0$ & $100.00 \%$ \\
\hline Total & $\mathbf{6 1}$ & $\mathbf{1 0 0 . 0 0 \%}$ & $\mathbf{1 2 2}$ & $\mathbf{1 0 0 . 0 0 \%}$ \\
\hline
\end{tabular}

Table 4: Perineal pain score on $3^{\text {rd }}$ postpartum day by $100 \mathrm{~mm}$ VAS on bed rest and sitting.

\begin{tabular}{|c|c|c|}
\hline Perineal pain & \multicolumn{2}{|c|}{ Moderate to severe pain } \\
\hline & $\begin{array}{l}\text { Cases }(\%) \\
(n=61)\end{array}$ & $\begin{array}{l}\text { Controls }(\%) \\
(\mathrm{n}=122)\end{array}$ \\
\hline Bed rest & $4.92(3)$ & $7.38(9)$ \\
\hline Sitting & $39.34(24)$ & $51.64(63)$ \\
\hline Walking & $54.10(33)$ & $83.61(102)$ \\
\hline Defecation & $54.10(33)$ & $83.61(102)$ \\
\hline
\end{tabular}

*The visual analog scale (VAS) is one of the most commonly used measures of pain intensity in pain research. 100-mm VAS ratings of 0 to $4 \mathrm{~mm}$ considered no pain; 5 to $44 \mathrm{~mm}$, mild pain; 45 to $74 \mathrm{~mm}$, moderate pain; and 75 to $100 \mathrm{~mm}$, severe pain.

In this study, no correlation was found between episiotomy requirement and maternal age, perineal length, gestational age from 36 to 40 weeks, birth weight (up to $<3500 \mathrm{gm}$ ) in selective episiotomy group in this study (Table 5).

Table 5: Distribution of patients having episiotomy or $2^{\text {nd }}$ degree perineal tear by birth weight in case group.

\begin{tabular}{|lll|}
\hline Birth weight & Total & $\begin{array}{l}\text { Episiotomy+2 } \\
\text { degree tear }(\%)\end{array}$ \\
\hline $1500-1999 \mathrm{gm}$ & 0 & 0 \\
\hline $2000-2499 \mathrm{gm}$ & 10 & $6(60 \%)$ \\
\hline $2500-2999 \mathrm{gm}$ & 36 & $23(63.9 \%)$ \\
\hline $3000-3499 \mathrm{gm}$ & 15 & $10(66.67 \%)$ \\
\hline Total & $\mathbf{6 1}$ & $\mathbf{3 9}$ \\
\hline
\end{tabular}

$\mathrm{p}$ value $=0.95$.

\section{DISCUSSION}

In the prospective observational study done by Saxena Rajivkumar et al, episiotomy was given in $96 \%$ of control 
group and $40 \%$ of case group in primipara, $13 \%$ have second degree tear and $2 \%$ have $3^{\text {rd }}$ or $4^{\text {th }}$ degree perineal tear. This translated into $41 \%$ reduction in the number of perineal lacerations in primipara, which is comparable to our study where reduction in the major perineal lacerations ( $2^{\text {nd }}$ degree or more) by $36.07 \% .^{5}$

In the study done by Ali SS et al, in primigravida, episiotomy was made in $32 \%$ of deliveries in the selected and $100 \%$ in the routine group. Severe perineal trauma was not seen in either group. Anterior vaginal/ paraurethral trauma was more common in the selected group. $48 \%$ women in selected group required surgical repair of posterior perineal trauma while $100 \%$ in routine group. 6

In study done by Eltorkey MM et al, episiotomy rate in elective group was $83 \%(\mathrm{n}=100)$ and in selective group is $53 \%$ but with higher $(8 \%)$ second degree perineal lacerations in primigravida women. ${ }^{7}$ In the study done by Harrison RF et al, 92 patients allocated not to undergo episiotomy, seven $(8 \%)$ had one done for medical reasons compared with $507(89 \%)$ in the patients allocated to undergo episiotomy. First degree tears occurred in 23 $(25 \%)$ and second-degree tears in $43(47 \%)$. Nineteen $(21 \%)$, however, retained an intact perineum compared with only $35(6 \%)$ of the women who had delivered in other group, which is comparable to our study where intact perineum was found in $22.95 \%(n=14)$ patients. $^{8}$ In the study done on nulliparous women by Juste-Pina A et al, episiotomy was performed in $83.7 \%$ in the routine group and in $59 \%$ in selective group. The incidence of subsequent perineal tear was higher in selective episiotomy group (30\%) than in routine episiotomy group. ${ }^{9}$

According to Cochrane database 2017, for pain, it's not clear that if selective episiotomy compared with routine results in fewer women with moderate or severe perineal pain (measured on a visual analogue scale) at three days postpartum (RR $0.71,95 \%$ CI 0.48 to 1.05 , one trial, 165 participants, very low-certainty evidence). ${ }^{3}$

While in our study, perineal pain score by $100 \mathrm{~mm}$ VAS on $3^{\text {rd }}$ day postpartum is significantly less in selective episiotomy group.

\section{CONCLUSION}

Selective use of episiotomy with good clinical judgment in primigavida can improve maternal outcome by reducing perineal lacerations and those having intact perineum can have the best outcome when episiotomy is given selectively.

Funding: No funding sources

Conflict of interest: None declared

Ethical approval: The study was approved by the Institutional Ethics Committee

\section{REFERENCES}

1. Dutta DC, Konar H. DC Dutta's textbook of obstetrics including perinatology and contraception. New Delhi, India: Jaypee, The Health Sciences Publisher; 2013:568.

2. Hale R, Ling F. Episiotomy: procedure and repair techniques. Am College Obstet Gynecol. 2007;4. Available

at: https://www.scribd.com/doc/285746166/EpisiotomyACOG. Accessed on $3^{\text {rd January } 2020 .}$

3. Jiang H, Qian X, Carroli G, Garner P. Selective versus routine use of episiotomy for vaginal birth. Cochrane Database Syst Rev. 2017;(2):8.

4. Clemens D. ACOG: New Recommendations on Obstetric Lacerations. 2016. Available at: https://anesthesiaexperts.com/uncategorized/acogrecommendations-obstetric-lacerations. Accessed on $3^{\text {rd January } 2020 .}$

5. Saxena R, Sandhu G, Babu K, Bandol H, Sharma G. Restricted use of episiotomy. The J Obstet Gynecol India. 2010;60(5):408-12.

6. Ali SS, Malik M, Iqbal J, Faruqi NJ. Routine episiotomy versus selective episiotomyin primigravidae. Annals King Edward Med Univer. 2014;10:4.

7. Eltorkey MM, Nuaim MA. Episiotomy, elective or selective: a report of a random allocation trial. J Obstet Gynaecol. 1994;14(5):317-20.

8. Harrison RF, Brennan M, North PM, Reed JV, Wickham EA. Is routine episiotomy necessary? $\mathrm{Br}$ Med J (Clin Res Ed). 1984;288(6435):1971-5.

9. Juste-Pina A, Luque-Carro R, Sabeter-Adan B, Miguel E, Vinerta-Serrano E, Cruz-Guerreio E. Selective episiotomy versus routine episiotomy in nulliparous women with vaginal delivery performed by midwives. Matronas Profession. 2007;8:5-11.

Cite this article as: Modi DA, Vaishnav PP. Routine versus selective use of episiotomy in primigravida: a prospective non-randomized case-control study. Int $\mathbf{J}$ Reprod Contracept Obstet Gynecol 2020;9:1003-6. 